\title{
Consultative participation in Brazil: the case of the São Paulo Municipal Advisory Board
}

Fernanda Lima-Silva 1

Kate Abreu 1

Esther Leblanc ${ }^{1}$

1 Fundação Getulio Vargas (FGV EAESP) / Escola de Administração de Empresas de São Paulo, São Paulo / SP — Brazil

\begin{abstract}
This article analyzed the São Paulo Municipal Advisory Board, an innovative channel of communication between civil society and the local government's executive branch. This exploratory research is based on an intrinsic case study, aiming to understand the operation of this advisory board and how it relates to other participatory instances in Brazil. The study adopted semi-structured interviews with members of the advisory board and representatives of the local government, participant observation of meetings of the management's board, and analysis of official documents. Data were analyzed based on the theory of deliberative democracy and studies on participatory bodies. The results indicate that the São Paulo Municipal Advisory Board is partially aligned with the deliberative democracy, and strongly connected to the federal and state-level Economic and Social Development Advisory Boards. Due to the specificities of these instances, we suggest the creation of a new category in the literature on institutional participation - "Governmental Advisory Board."
\end{abstract}

Keywords: public administration; deliberative democracy; participatory institutions; councils; social participation.

\section{Participação consultiva no Brasil: o caso do Conselho da Cidade de São Paulo}

Este artigo tem como objeto analítico o Conselho da Cidade de São Paulo, um canal inovador de comunicação entre a sociedade civil e o executivo municipal. Esta pesquisa exploratória é baseada em um estudo de caso intrínseco, tendo como objetivos compreender o funcionamento desse conselho e relacioná-lo a outras instituições participativas no Brasil. Para isso, foram realizadas entrevistas semiestruturadas com conselheiros(as) e representantes da gestão municipal, observação participante em reuniões do comitê gestor e análise de documentos oficiais. Os dados foram analisados a partir da teoria sobre democracia deliberativa e de estudos sobre conselhos participativos. Os resultados apontam que o Conselho da Cidade de São Paulo está parcialmente alinhado ao modelo deliberativo de democracia, e fortemente aos exemplos federal e estadual de Conselhos de Desenvolvimento Social e Econômico. Pelas especificidades dessas instâncias, sugerimos a criação de uma nova categoria na literatura sobre participação institucional - "Conselho Consultivo".

Palavras-chave: administração pública; democracia deliberativa; instituições participativas; conselhos; participação social.

\section{Participación consultiva en Brasil: el caso del Consejo de la Ciudad de São Paulo}

Este artículo tiene como objeto analítico el Consejo de la Ciudad de São Paulo, un innovador canal de comunicación entre la sociedad civil y el Ejecutivo municipal. Esta investigación exploratoria se basa en un estudio de caso intrínseco cuyos objetivos son comprender el funcionamiento de ese consejo y relacionarlo a otras instituciones participativas en Brasil. Para ello, se realizaron entrevistas semiestructuradas con consejeros y representantes de la gestión municipal, observación participante y análisis de documentos oficiales. Los datos se analizaron a partir de la teoría sobre democracia deliberativa y de estudios sobre consejos participativos. Los resultados apuntan que el Consejo de la Ciudad de São Paulo está parcialmente alineado con el modelo deliberativo de democracia, y fuertemente con los ejemplos federal y de los estados de consejos de desarrollo social y económico. Por las especificidades de estas instancias, sugerimos la creación de una nueva categoría en la literatura sobre participación institucional: "Consejo Asesor".

Palabras clave: administración pública; democracia deliberativa; democracia participativa; consejo; participación social.

DOI: http://dx.doi.org/10.1590/0034-761220180427x

Article received on December 19, 2018 and accepted on February 03, 2020.

ISSN: $1982-3134$ @ (1)

The research that originated this article was funded by the Coordination for the Improvement of Higher Education Personnel - Brazil (CAPES) - Finance Code 001.

[Original version] 


\section{INTRODUCTION}

Over the last few decades, a confluence of development and democratization agendas has brought citizen engagement in governance to center stage, anchored in the belief that participatory spheres can enhance democracy, improve the effectiveness of public policies and make better citizens and better government (Cornwall \& Coelho, 2007). The maturation and expansion of these participatory practices around the world have generated extensive literature on their genealogy and implementation processes (Avritzer, 2012).

Researches have also acknowledged the challenges of participatory institutions. They point to the fragility of the mechanisms (Coelho, 2014), the difficulties of promoting meaningful participation of poorer and marginalized citizens (Coelho, 2013; Cornwall \& Coelho, 2007), the uncertain democratic nature of these spaces (Casula, 2017) and the low effectiveness and the consequent demobilization around participation (Crantschaninov, 2018).

Furthermore, many authors have indicated that social participation can assume varied forms, highlighting the need to understand the characteristics of different participatory spheres (Avritzer, 2012; Bishop \& Davis, 2002) and the importance of contextualizing them with regard to the social, cultural and political landscapes where they are situated (Cornwall, 2004). Therefore, in accordance with Bishop and Davis (2002, p. 2), we consider that "participation is the expectation that citizens have a voice in policy choices", and it can take different institutional formats.

In Latin America, from the 1980's onwards, countries have experienced redemocratization processes that enabled them to explore new ways for civic participation. The participatory institutions in the region is an established and well-studied phenomenon today (Avritzer, 2012) and Brazil is the country that has seen the greatest expansion of opportunities for civic participation in state-created institutions (Cornwall, 2004). Notwithstanding, Participatory Budgeting still appears to be the most well-known Brazilian participatory mechanism. Hence, Avritzer (2012) argues for the relevance of understanding other forms of institutionalised participation in Brazil.

Against this background, São Paulo becomes an interesting case for analysis. It is one of the most influential cities in Latin America - rife with inequality, harbouring multiple interests, and with conflicts over its economic, social, political and cultural assets. The capacity of the municipality to manage such conflicts and deal with asymmetrical power relations is essential to make it socially inclusive and diverse.

In 2013, the newly elected Mayor, Fernando Haddad (from the Workers Party), publicly presented the goals of his mandate (2013-2016) ${ }^{1}$, which included initiatives to promote participation, transparency and the involvement of society in the Municipal Public Administration. Among those planned actions, Goal n. 113 mentioned the creation of the São Paulo Economic and Social Development Advisory Board, which later became known as the São Paulo Municipal Advisory Board (here in after 'CCSP'2).

The decision to create this institution was underpinned by the understanding that, in municipalities as large and complex as São Paulo, resolving problems becomes challenging if circumscribed only

\footnotetext{
${ }^{1}$ The 30/2008 amendment to the Law of the City of São Paulo establishes that every newly elected mayor must, within ninety days after his/her taking office, present the Goals Program of its administration, containing strategic actions, indicators and quantitative targets for each sector of the Municipal Public Administration.

${ }^{2}$ CCSP is the abbreviation for Conselho da Cidade de São Paulo, the name in Portuguese of the advisory board, and it will be used from now on in the article.
} 
to governmental interest and action. Therefore, answers to such problems are of better quality when they involve different perspectives from civil society, government, private organisations, etc - in the formulation of their agenda and study of the alternatives.

Assuming that CCSP is an innovative channel of dialogue between civil society and the municipality, and that it differs from other Brazilian participatory institutions, this Advisory Board becomes an interesting case for analysis. This is reinforced by the recognition that this institution remains understudied and quite unheard-of within public administration, public policies and social science literature.

Aiming to contribute to the debate on participatory institutions in Brazil, the research in this article is both exploratory and qualitative, aiming to answer two questions. Firstly, how does CCSP work? We assume that there is a gap between the official discourse on this participatory institution and its practice. Secondly, how does CCSP relate to other participatory institutions in Brazil? To answer our research questions, we propose a theoretical lens based on two main sources of literature: a review of participatory and deliberative democracy concepts and of the Brazilian experience with participatory institutions, with a focus on participatory councils.

The following text is structured in six sections. First, a revision of theories on participatory and deliberative democracy, followed by a review of participatory councils in the Brazilian context. Thirdly, the methodological procedures used for data collection and analysis. Soon after, CCSP is presented with more details. In the fifth section, the research findings are contrasted with theories on participatory democracy and institutions. Lastly, final considerations are displayed.

\section{MODELS OF DEMOCRACY: PARTICIPATORY AND DELIBERATIVE (AND ITS CRITICS)}

Analysis of the relationship between government and society has developed over the years. Understanding democracy is complex, as the concept, in addition to having been transformed several times throughout its history, is characterised by polysemy. As pointed out by Nobre (2004), several models of democracy coexist, with the following being the most influential in the contemporary debate: Elitist (or Schumpeterian), Pluralist, Legal, Participatory and Deliberative. In view of the purposes of this research, the first three models, which defend the minimum state and/or representation as a political principle, will not be addressed.

Our reflection acknowledges the central debate in contemporary democratic theory, which refers to the crisis of representative institutions, including political parties, which can no longer express the diversity existing in contemporary societies (Vizeu \& Bin, 2008; Fleury, 2006). Complementarily, Wampler (2010) notes that representative democracy no longer responds to the need for establishing a good relationship between government and society, which would then be filled by participatory democracy.

The participatory and deliberative models criticise the political representation (Nobre, 2004), as they advocate a deeper form of democracy, including broadening direct civic participation in the decision-making processes on collective issues. The participatory model is linked to the contestatory movements of the 1960s, with Carole Pateman, Nikos Poulantzas, and C. B. Macpherson as exponents. This model is based on the understanding that capitalism crystallizes inequalities, so it is necessary to overcome material and political inequalities by increasing participation in decision-making processes. 
The deliberative model is commonly organised around the view that the exercise of collective political power is based on public and rational argumentation among equals. Therefore, democratic processes are guided by discussion of the public good and they value arguments, dispensing emotions. It is an explicitly normative theory of democracy, based on rational argumentation and respect for impartial deliberation procedures. Among the paradigmatic authors of this model are Jurgen Habermas, Bernard Manin, and Joshua Cohen.

While recognising the important innovations brought by participatory and deliberative models, recent research problematizes these theories. Iris Young (2001) identifies two problems with the deliberative model. First, by restricting democratic discussion to critical argumentation, there is a tendency to silence or devalue certain people or groups. Secondly, there is an incorrect assumption that the discussion between the parties must necessarily seek a common element of understanding. Similarly, Coelho (2013) disagrees with the notion that deliberative arenas should be insulated from political passions and suggests that the participation of mobilised social actors contributes to the increased effectiveness of these forums.

Additionally, Teixeira, Souza, and Lima (2012) observed that, even if one wishes to promote the exchange of ideas, if there is no guarantee of representative diversity, there will be no effective exchange. They return, therefore, to Young's work (2006), in which inclusion is seen as a way of qualifying representation in participatory spaces, since social perspectives would be represented there, and these are understood as experiences that individuals have because they are part of a certain group.

Moreover, taking into account that the participatory spaces also end up involving elements of representation, Céli Jardim Pinto, questions: "to what degree does the substitution of representation for participation as a way of solving the problems of representative democracy not fall within the same limits delineated by the first, without, however, maintaining its safeguards (2004, p. 97)"? This author and others note that one of the most heatedly debated issues of participation today refers to the dichotomy between democracy and inclusion, because in societies with high inequality there is a significant challenge of the inclusion of the poorer and more marginalised citizens (Cornwall \& Coelho, 2007).

In short, participatory and deliberative models emerged as attempts to minimise the problems encountered with representation. In spite of their recent expansion and advances, their implementation is not neutral and they face their own set of challenges.

\section{PARTICIPATORY COUNCILS IN BRAZIL}

Studies have noted the existence of a wide variety of councils ${ }^{3}$ in Brazil. To Szwako (2012), participative institutions date from the mid-50s, encompassing base ecclesial communities, clubs for mothers, residents associations, etc. In the 1980s, both community and popular councils emerged (Souto $\& \mathrm{Paz}, 2012)$, with organisational arrangements anchored at the base of Brazilian society, strongly connecting local problems with the claim of rights.

These articulations were important for the Brazilian redemocratization process, which resulted in the elaboration of a new Constitution, in 1988, which established institutionalised participatory

${ }^{3}$ In Portuguese, the word "conselho" is used to refer to various types of participatory institutions, including Governmental Advisory Boards, Public Policy Council and Popular Council. However, in English, it was not possible to use the word 'council' for all these institutions, particularly because "City Council", the literal translation for Conselho da Cidade, is a term already used to refer to the legislative body that governs a city. That is the reason why, when referring to CCSP, we use the term 'Municipal Advisory Board'. 
spaces, where the State and society were responsible for the formulation, execution and control of policies (Szwako, 2012) ${ }^{4}$.

Furthermore, Brazil also has experience with corporatist councils, characterised as "a mechanism of confrontation of interests and negotiation of consensuses among socially constituted actors" (Fleury, 2006, p. 6). These collective experiences of concertation can be capable of aggregating different interests and solving conflicts and governance problems, growing in a scenario of discredited governmental authorities.

In the republican period, from the 1930s onwards, the Brazilian national developmental model, led by an authoritarian state, generated a kind of relationship with society characterised by O'Donnell (1976) as bifrontal. On the one hand, the state subordinates the fragile civil society, installing state institutions to organise social interests. On the other, the state is privatised, acting to benefit the economic elite. In 1944, the National Council of Industrial Policy and Commerce was created, merging the economic governmental bureaucracy and public managers, with associations of entrepreneurs and commerce. This tendency was also followed in Getulio Vargas' second government with the National Economy Council; and with the Executive Groups under the government of Juscelino Kubitscheck.

More recently, in 1991, the Sectoral Chambers were introduced, which were also forms of negotiation between the private initiative and the governmental elite. However, they differ in that they recognise workers organisations as being important actors in the negotiations, thus forming a tripartite design.

It seems that a new type of council was established in the administration of Luiz Inácio Lula da Silva (2003/2010). The Economic and Social Development Advisory Board (CDES $)$, created in 2003, was based on a closer relationship between state and society, "generating a new institutionalized and plural space in which different political actors and the government meet, enabling a process of social concertation and new foundations to guarantee governability" (Fleury, 2006, p. 11). To Fleury, this was the most recent example of "concerted democracy" to take place in Brazil. She sees it as a social innovation because, in a society marked by inequalities, it introduced the same discussion space to social actors that had not previously interacted, thus expanding the public sphere. It is important to note that the CDES, unlike the corporatist councils, does not aim at creating consensus between economic stakeholders, but at gathering a broad composition of relevant stakeholders to discuss specific policies and the economic and social development of the country.

Vizeu and Bin (2008) corroborate Fleury's view regarding the advisory and non-deliberative role of CDES but problematise some aspects of how it functions. Similarly to the challenges identified by the participatory institutions literature, previously mentioned, they point out the difficulty of recognising the political equality of all participants and the low effectiveness of the decisions of CDES.

In addition, Santos (2016) recently analysed the Economic and Social Development Advisory Board of the State of Rio Grande do Sul. To this author, this Advisory Board resembled the CDES in terms of characteristics and challenges for effectiveness. Among its achievements, this institution has contributed to the improvement of the content of public policies, transparency, and increased access to information. However, the composition criteria and the reduced capacity to influence the agenda minimized the deliberative potential of the advisory board. The research also revealed high

\footnotetext{
${ }^{4}$ According to Teixeira, Souza, and Lima (2012), popular councils were the embryos of the Policy Councils and their expansion took place largely due to new legal requirements for financial resource distribution.

${ }^{5} \mathrm{CDES}$ is the abbreviation for Conselho de Desenvolvimento Econômico e Social (its original name in Portuguese), and it will be used from now on in the article.
} 
dependency on the political will of the governor, with uncertainty surrounding whether the institution would continue under subsequent governments.

In short, this section points out that very different types of institutional arrangements have been termed councils. They range from popular councils, those more permeated in the social fabric and related to popular autonomy, to corporatist councils, which gathered representatives of business and workers together with government for concertation and negotiations. They also encompass Economic and Social Development Advisory Boards, forums involving the federal or state government and different political actors to promote social concertation and governability. They have very different formats, concepts and purposes and, to better analyse them, the next subsection will present studies that outline the councils' main characteristics.

\subsection{Typology of Recent Participatory Councils in Brazil}

Avritzer (2012) indicates that the new Brazilian has generated three main designs for public participation: bottom-up, power sharing and ratification. We focus primarily on this author's second type - power-sharing, which is an institutional design where both state and civil society participate and explicitly encompasses councils. Cohn (2011) explains the dual function of the council: enabling the demands of society to be heard by the state and thereby bringing the definition of public policies closer to the needs of the population. Teixeira et al. (2012, p. 51) argue that participatory institutions function in different ways, depending on: "the context of institutionalisation, the type of social organisation, the definition of roles and the goals of the collegiate, and the delimitation of their capacities". For the authors, a council can be defined, generally, as a space of deliberative or consultative character, in which there is a certain permanence in time. They present a very useful categorisation of the various roles of councils, shown in Box 1.

BOX 1

PREDOMINANT ROLES AND TARGET AUDIENCE/ TYPE OF PARTICIPATORY COUNCILS

\begin{tabular}{|c|c|c|}
\hline Type of Councils & Predominant roles & Target audience \\
\hline \multirow[t]{2}{*}{ Public Policies Council } & Establishes guidelines, priorities and procedures & Specialists \\
\hline & $\begin{array}{l}\text { Decision-making shared with government } \\
\text { representatives. }\end{array}$ & $\begin{array}{l}\text { Interests in conflict (e.g., capital and labour) } \\
\text { and the State for mediation }\end{array}$ \\
\hline Rights Council & $\begin{array}{l}\text { Coordinates, monitors and evaluates policies, } \\
\text { promotes participation and guides different } \\
\text { publics }\end{array}$ & $\begin{array}{l}\text { Marginalised from the political system (popular } \\
\text { and identity movements) }\end{array}$ \\
\hline Funds Council & $\begin{array}{l}\text { Approves plans of accounts and funds } \\
\text { management reports }\end{array}$ & $\begin{array}{l}\text { Interests in conflict (e.g., capital and labour) } \\
\text { and the State for mediation }\end{array}$ \\
\hline & $\begin{array}{l}\text { Judges processes and grants benefits to certain } \\
\text { organisations. }\end{array}$ & \\
\hline
\end{tabular}

Source: Teixeira et al. (2012, pp. 58-59). 
By separating participatory councils according to their mode of operation and purpose, characterising their predominant roles and public, the authors allow comparisons between them, providing interesting analytical input for this research and the analysis of the CCSP. Is it also noteworthy mentioning that these recent reviews on participatory councils do not include corporativist or concertational councils, like CDES or CCSP.

\section{METHODOLOGICAL PROCEDURES}

The methodological approach is based on the logic of the intrinsic case study (Stake, 2008). This case study type is chosen when one wants better understanding of a particular case, because of an intrinsic interest in it. The purpose is not to understand some generic phenomenon or abstract construct, nor theory building - though at other times the researcher may do just that. Due to this methodological choice, anchored on non-positivist traditions, the structure of the article does not conform to the basic beliefs of the positivist paradigm, such as verification of hypothesis, and specification of objective independent and dependent variables.

This research links the methodology of a case study with three other techniques associated with this research tradition - documental analysis, participant observation and interviews. Considering that qualitative research, when compared to quantitative studies, is subject to a higher degree of subjectivity in their procedures, selection, and management and analysis of their data, as described by Beltrão and Nogueira (2011), it requires as much clarity and transparency as possible when reporting the procedures adopted by researchers, as detailed below.

Data collection took place in two stages, with different goals. The documental analysis was adopted as an initial research strategy, aiming to capture how governmental documents described this institution and its work. Publicly available documents were reviewed, such as the creation of the advisory board decree and its institutional website. However, differently from other public policy councils, CCSP's website did not provide public access to the minute of all its meetings. Some minutes were initially available online, but they became inaccessible after the interruption of the Advisory Board activities.

The interviewees also shared the CCSP internal regulation, which detailed the goals and rules of the advisory board, its structure and composition, including the Work Groups, the Plenary and the Steering Committee. Regarding the participant observation, the researchers participated in two meetings of the CCSP Steering Committee in October and November 2015. At the beginning of these meetings, the Coordinator introduced the researchers to the Advisory Board members. The content of these meetings was registered in field notes, and posteriorly converted in expanded write-ups.

In addition, we conducted five interviews with advisors and public servants from the municipality who had worked at CCSP (the questions used in the interviews are displayed in Annexe 1). With reference to the interviews, they were conducted between October and November 2015 (one of the informants was interviewed again in October 2019), the respondents were chosen intentionally, considering the sector in which they worked and the opportunities we had to access them. To preserve their identity, the interviewees were named Interviewee A, B, C, D, and E, as shown in Box 2. The interviews were conducted based on a semi-structured script, they lasted from forty minutes to one hour, were fully recorded, transcribed and coded, thereby facilitating their subsequent analysis. 


\begin{tabular}{|c|c|c|c|}
\hline Interviewee & Institution* & Role & Date of interview \\
\hline A & $\begin{array}{l}\text { Municipal Secretariat of } \\
\text { Governmental Relations }\end{array}$ & $\begin{array}{l}\text { Formulation and implementation } \\
\text { of the CCSP }\end{array}$ & $\begin{array}{c}\text { October/2015- } \\
\text { October/2019 }\end{array}$ \\
\hline B & CCSP & Adviser and University professor & November/2015 \\
\hline C & $\begin{array}{l}\text { Municipal Secretariat of } \\
\text { Governmental Relations }\end{array}$ & $\begin{array}{l}\text { Formulation and implementation } \\
\text { of the CCSP }\end{array}$ & November/2015 \\
\hline D & $\begin{array}{l}\text { Municipal Secretariat of } \\
\text { Governmental Relations }\end{array}$ & Coordination of the CCSP & November/2015 \\
\hline$E$ & CCSP & Adviser and NGO director & November/2015 \\
\hline
\end{tabular}

Source: Elaborated by the authors.

${ }^{*}$ Municipality respondents were not necessarily working with the CCSP at the time of the interview, but they were chosen because they had worked within the CCSP.

A basic coding strategy was used to support the analysis of the collected data. Codes are understood here as labels that assign meaning to the descriptive or inferential information compiled. They can be used to retrieve and categorise similar data chunks, allowing the researcher "to quickly find, pull out and cluster the segments relating to a particular research question (...)"' (Miles \& Huberman, 1994, p. 57). This research simultaneously used two first-cycle coding approaches: descriptive and evaluation. The descriptive approach assigns code to data, summarising in a word, or short phrase, the basic topic of a passage of qualitative data. The evaluation coding applies codes that assign judgements on the merit, worth or importance of programs or policy. That said, the analysis of the data was based on the following codes: roles \& tasks, composition, selection of advisers, the content of meetings, consultative vs deliberative, CCSP vs CDES, evaluation of CCSP and its functional dynamics, and challenges.

\section{SÃO PAULO MUNICIPAL ADVISORY BOARD}

São Paulo Municipal Advisory Board will be presented in an analytical and structured way, with these subsections: roles, participants, institutional structure following Teixeira et al. (2012) and evaluation from the interviewees perspective.

\footnotetext{
${ }^{6}$ This excerpt - as well as others obtained from articles, research and interviews in Portuguese - was translated by the authors into English.
} 


\subsection{São Paulo Municipal Advisory Board and its Roles \& Tasks: Why does it Exist?}

According to its Creation Decree (Decree n. 53.796, 2013) and Internal Regulation, the CCSP is an "immediate advisory body to the mayor in implementing the economic, social and environmentally sustainable development of the City of São Paulo." According to the latter document, it aims to promote citizenship and social participation as a method of government. Its main roles are:

1) Advise the Mayor on the formulation of policies, normative indications and specific governmental actions;

2) Debate, guide and evaluate public policy proposals and structural reforms submitted by the mayor;

3) Suggest, propose, elaborate and present reports, studies, projects and agreements, gathering contributions from various sectors of civil society for the mayor;

4) Organize, promote and follow debates on the necessary measures for the promotion of the economic, social and environmental development of the city

The formal definitions of the roles of CCSP, in light of participatory democratic theories, seem ambiguous. After all, it aims to promote social participation as a method of government, in which citizens should have greater involvement with municipal decision-making processes. At the same time, the CCSP is described as an advisory body to the Mayor, giving it a counselling character. In this regard, the Advisory Board could be viewed as a deliberative space, where the participants conduct rational discussions focused on the public good, assisting the mayor in making decisions.

However, this preliminary definition, demands rethinking in light of the data from the interviews. According to interviewee A, the CCSP has the following roles: (1) to serve as a gauge or thermometer of the proposals of the executive branch; (2) to discuss policies that are important to the city and (3) to be a space of support to governmental actions. In turn, interviewee B argues that she has doubts about the advisory role of the CCSP, since there were occasions when the mayor did not consider recommendations from the Advisory Board.

In contrast, interviewee $\mathrm{C}$ describes the CCSP a space for dialogue and sharing different perspectives, which levels the members understanding of society. In addition, she identifies an innovation: the CCSP is viewed as a place of accountability from the ruler to the governed. Finally, according to another interviewee, the Advisory Board actually advises, in addition to being able to present proposals more proactively.

In fact, the interviews point to a common characterization of the CCSP based on the instruments of the deliberative democracy model, departing from corporatist councils and their negotiation style. The CCSP was often described in the interviews as an argumentative space, a place of debate, exchange of opinions and perspectives, and not as a decision locus. It is important to emphasize that the interviews also indicated the deliberative limits of the institution: advisers are free to debate and to suggest, but the final word belongs to the mayor, who listens and decides. 


\subsection{São Paulo Municipal Advisory Board and its Advisers: Who Participates?}

CCSP members are not elected by the population, but appointed by the municipal chief executive. According to its internal regulation (Art. 3. III), the advisory board is composed of up to 90 citizens of "notorious representativeness and recognized social, economic and environmental performance" who can contribute, through their experience and knowledge, to the sustainable development of the City.

This description of the advisers selection seems to indicate that the mayor has considerable discretionary power. On the one hand, the mayor does not seem to benefit from this power alone, which can be exemplified by the words of Interviewee D: "there is a possibility of designation, but in fact, the mayor chooses based on a list of names and several people contribute to it". On the other hand, the same interviewee notes that the selection criteria are unclear:

There is not an established rule, we define [the advisers selection] based on loose criteria. There are no predefined criteria. When I say 'we', I actually mean the mayor. But, like everything in City Hall, there is a previous screening (...) Actually, what really happens is that it is extremely subjective (Interviewee D).

The element of subjectivity in the selection of advisers reappears in other interviews, for example, in the following excerpt: "the Mayor chooses the sectors with whom he wants to dialogue. But Haddad is a Republican, so he did not form a 'pals' Advisory Board" (Interviewee A). The interviewees note that CCSP is composed by a group with 'limited diversity' (Interviewee A), representing the vision of segments of society that are sympathetic with the Workers Party and its proposals (Interviewee D) or at least are open to dialogue. In fact, some people from opposition parties, like the Social Brazilian Democracy Party (PSDB) and the Brazilian Democratic Movement Party (PMDB), participate in the advisory board.

According to the CCSP official website ${ }^{7}$, there is an effort to have representatives from different sectors of society, such as "social movements, business community, trade unionists, intellectuals, press, religious leaders, educators, researchers, scientists, minorities, constituted powers etc.". However, there are differences between advisor profiles when the Advisory Board compositions are compared (the advisers are elected for two years: the first term was in 2013/2015 and the second, 2015/2017). The main change is the absence, in the second composition, of members from the Judiciary system and religious institutions (Graphic 1). According to Interviewee A, the decision not to maintain these members in CCSP's second composition was taken in a Steering Committee meeting, based on the shared understanding that members from these institutions had not properly engaged in the Council activities.

\footnotetext{
${ }^{7}$ This website (http://conselhodacidade.prefeitura.sp.gov.br/) was online during the execution of this research, but it went offline after the election of Mayor João Doria (Brazilian Social-Democracy Party), in 2017.
} 


\section{GRAPHIC 1 COMPOSITION OF THE SÃO PAULO MUNICIPAL ADVISORY BOARD: 2013 E 2015}

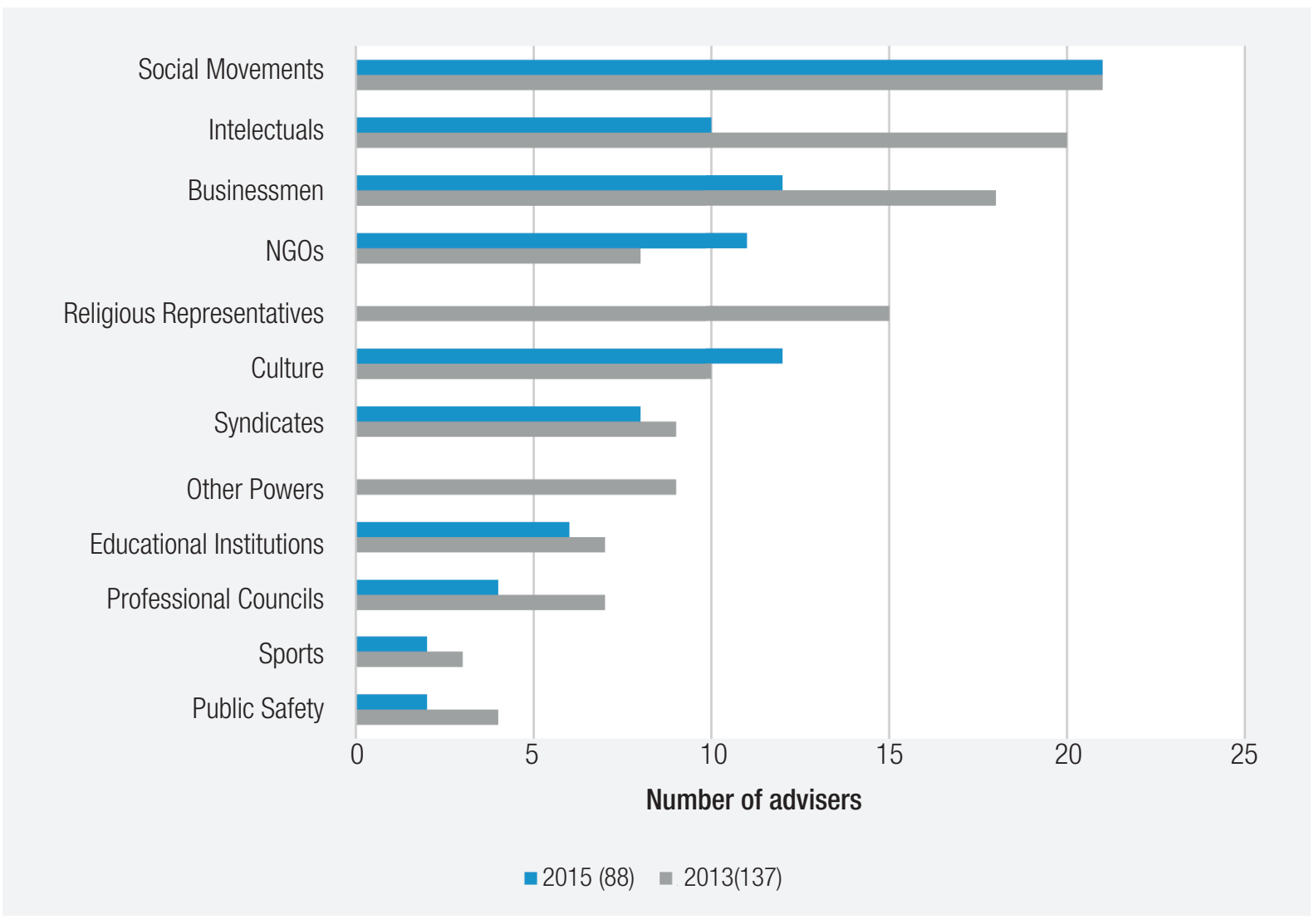

Source: Elaborated by the authors based on data shared by the interviewees.

The graphic also reveals a decrease in the number of members. In its first composition, CCSP had 137 advisers coming from civil society, municipal public administration and other state institutions, for example, the Public Prosecutor's Office and the Military Police, while in the second composition this number was reduced to 90 .

In sum, given that the selection of councillors is an exclusive prerogative of the Mayor, based on 'notorious representativeness', some questions arise. First, as Pinto (2004) notes, this selection process can potentialize the dichotomy between democracy and inclusion, since a significant part of the population remains excluded from these spaces. Secondly, there was no clear evidence of accountability for the advisers to the groups they represent, raising questions on the extent to which participation maintains the same problems of the representative democracy, without guaranteeing their safeguards (such as an election).

\subsection{The Institutionality of the CCSP}

CCSP integrates the Municipal Secretariat of Governmental Relations (SMRG), whose purpose is to politically coordinate the executive branch, and its relationship with the legislative branch, civil society and other institutions. During the period from 2013 to 2015, the SMRG had four different 
managers, and the coordinator of the CCSP changed twice. For interviewee E, such frequent changes negatively affected the CCSP since, in their words, "the social memory is lost". Indeed, the turnover in this context may lead to poor performance, considering that, according to Wampler (2010), the success of participatory institutions depends on the public authorities commitment.

Regarding its institutional structure, CCSP has an Executive Secretariat, responsible for its management within SMRG, which is integrated by public servants from this Secretariat and placed hierarchically below the SMRG Secretary Office. In addition, CCSP is composed of the Plenary, Steering Committee and Work Groups.

Plenary meetings are both regular and extraordinary meetings, and they involve all advisers, the mayor and some municipal secretaries. Following its internal regulation, the Plenary meets regularly, four times a year, by the call of the mayor. Besides it can have extraordinary meetings whenever the Mayor decides to consult the advisers on relevant matters or at least $30 \%$ of the members request such assemblies. Changes in the agenda of regular meetings, as well as calls for extraordinary assemblies, must be informed 48 hours in advance.

The Steering Committee is a CCSP internal body, whose function is to discuss matters of relevance to how the advisory board functions, as well as to propose and discuss agendas and relevant issues and assist the Executive Secretariat in its work. This Committee is composed of $10 \%$ of the advisers, elected among the members of the collegiate for one year. Work groups are created based on the suggestion of a group of at least 15 members. Two were active in 2015 - Urban Mobility and Training for Citizenship: Human Rights and Diversity.

Although CCSP mechanisms and spaces are formally organized, the interviews indicated that their real functioning dynamics differed from expectations. They pointed to the existence of "normative ambiguity" or lack of clear understanding on the roles of different participants, which may contribute to the low capacity the advisory board has in influencing the decision-making process. During one of the participant observations, at a Steering Committee meeting, for example, the advisers mentioned communication problems and lack of clarity on their roles in the relationship with the mayor and the Executive Secretariat.

In addition, data from the interviews and participant observations indicated that the topics covered in the CCSP plenary meetings were "urgent" in São Paulo, such as urban mobility, master plan, the water crisis, day care centres, etc. They also reveal that there is no clear evidence that CCSP has much influence on municipal public policy. Regarding the Open Streets municipal program, and more particularly, the "Paulista Aberta", CCSP had reasonable influence over the public decision. This was a controversial issue, and it was the favourable position that CCSP had that "gave [it] the strength to turn it into a government project" (Interviewee A).

In contrast, regarding urban mobility, the interviews showed that the majority of advisers were favourable to keeping public transportation tariffs unchanged during the June/2013 protests, a major turning point in the city and the Brazilian political context. But Mayor Haddad chose to increase it, not adhering to this recommendation. He only changed his mind after a decision by the Governor of São Paulo, Geraldo Alckmin, to keep the subway tariffs unchanged.

Despite this trajectory, based on Lima et al. (2014)'s three dimensions to analyze the institutionalization of public policy councils, we argue that CCSP had a reduced institutionalization. The first dimension refers to recognition by the state and it can be inferred by the normative act 
of creation, decision-making character and binding to statutes, policies or systems. Created by the Decree n. 53.796 (2013), CCSP did not have a deliberative character and could be revoked at any time by local authorities.

The second dimension relates to the availability of material, organizational and technical resources needed to fulfill the advisory board purposes. The existence of executive secretariat and working groups are aspects highlighted by Lima et al. (2014). Accumulated learning is the third dimension suggested by the authors, referring to the working time and the experience gained throughout it. CCSP was active only during the administration of Mayor Fernando Haddad, reinforcing the challenges of this Advisory Board in terms of institutionalization.

\subsection{São Paulo Municipal Advisory Board and its Evaluation}

When requested to evaluate CCSP, the interviewees gave remarkably diverse responses (Box 3). Positive aspects included the appreciation of a new channel of participation, where different perspectives attain visibility, and the fact that the Mayor can get closer to citizens and expose his plans to different sectors of the population. On the other hand, the evaluation of negative points and challenges was heterogeneous, reflecting clear differences based on the positions of the respondents. Government interviewees mentioned problems related to the lack of institutionalisation of CCSP, which generated excessive dependency on the mayor (and his interest in this space) and risks to its long-term sustainability. On their turn, advisers were concerned with the daily operations of the advisory board, such as the ability of them to listen to other points of view and the frequent change of secretaries at SMRG, impacting the CCSP performance.

Furthermore, a public manager mentioned a different concern, showcasing the complexities of dealing with the input of participatory institutions in daily work of government: the lack of governmental consensus on the role of the advisory board. Interviewee $\mathrm{C}$ mentioned that the CCSP Executive Secretariat was even blamed by parts of the government for 'exposing' the mayor during the June/13 protests.

GENERAL EVALUATION OF THE MUNICIPAL ADVISORY BOARD

\begin{tabular}{|c|c|c|c|}
\hline & Positive aspects & Negative aspects & Challenges \\
\hline Government & $\begin{array}{l}\text { - Advisory Board as a 'gauge' of the } \\
\text { represented social sectors and a } \\
\text { channel of participation. } \\
\text { - The mayor presents his opinion of the } \\
\text { city to the different social segments in a } \\
\text { unique space. } \\
\text { - Makes it possible to articulate and } \\
\text { strengthen organised civil society. } \\
\text { - Diversity of representations in a public } \\
\text { space. }\end{array}$ & $\begin{array}{l}\text { - Lack of internal consensus in } \\
\text { the Government about the role } \\
\text { of the advisory board. } \\
\text { - It is not an institutionalised } \\
\text { space, With no guarantee } \\
\text { of continuation in the next } \\
\text { government. }\end{array}$ & $\begin{array}{l}\text { - Dynamics of Public } \\
\text { Administration } \\
\text { (changes due to } \\
\text { elections). }\end{array}$ \\
\hline
\end{tabular}




\begin{tabular}{|c|c|c|c|}
\hline & Positive aspects & Negative aspects & Challenges \\
\hline Advisers & $\begin{array}{l}\text { - Possibility to listen to different points of } \\
\text { view. } \\
\text { - Space where previously unheard ideas } \\
\text { can be heard. }\end{array}$ & $\begin{array}{l}\text { - Political changes negatively } \\
\text { impacting the continuity of } \\
\text { work. }\end{array}$ & $\begin{array}{l}\text { - Advisers influence } \\
\text { depends on their } \\
\text { potential for listening } \\
\text { and persuasion. }\end{array}$ \\
\hline
\end{tabular}

Source: Elaborated by the authors, based on the interviews.

\section{BUILDING BRIDGES BETWEEN THEORY AND PRACTICE}

It is now necessary to return to the literature and build connections between this debate and our case study. Firstly, in regard to democracy models, the case analysis provides evidence that CCSP has traits linking it to the deliberative model. Despite recognising that the advisory board is distant from an ideal deliberation - while deliberative theory argues that participants, equal to each other, value rational argumentation and may change their opinion, CCSP members tend to defend a consolidated position and there is no collective search for consensus -, the CCSP was presented by several interviewees as an argumentative space, where different perspectives and opinions are disseminated. As a result, little-known ideas become more visible and different perspectives blossom in the same arena.

Secondly, with regard to types of council in Brazil, CCSP seems to have more similarity to CDES than to others already identified in the participation typologies. Thus, São Paulo Municipal Advisory Board does not focus on building consensus between a few organised groups, nor does it approach a specific public policy or theme, make allocation decisions, approve or reject government proposals or manage public funds. Its main features are similar to those found by Fleury's (2006) study on the CDES: in a city/country marked by inequalities and with complex social and urban problems, they introduce different actors that do not normally interact in the same dialogue space, contributing to an enlargement of the public sphere and of the perspectives involved in the discussion.

Vizeu and Bin (2008)'s findings on the effectiveness of the CDES also echo in the present study: CCSP seems to be a space for dialogue and a locus of governmental search for support and legitimation, more than a place to shape proposals for reforms resulting from the dialogue with representatives of society.

In short, CCSP was not assigned any responsibility previously ascribed to public policy councils. Chart 4 displays a re-reading of Box 2, suggesting the creation of a new type of council, the Governmental Advisory Board, based on the findings of this study and those regarding Federal CDES (Fleury, 2006; Vizeu \& Bin, 2008), and state level CDES (Santos, 2016).

To conclude, we have two observations. The diversity of themes approached within CCSP can be an explanatory reason for the clarity issues in its roles, as identified above. Even if all advisers have leadership experience and extensive knowledge, given the broad scope of the topics covered - involving any "urgent" topic in São Paulo, it is feasible to assume that members of this board often come across themes that they are neither familiar nor experienced with. 


\begin{tabular}{|c|c|c|}
\hline Type of Council & Predominant roles \& tasks & Target Audience \\
\hline Public Policies & $\begin{array}{l}\text { Establishes guidelines, priorities and } \\
\text { procedures } \\
\text { Decision-making shared with government } \\
\text { representatives. }\end{array}$ & $\begin{array}{l}\text { Specialists and interests in conflict (e.g. capital and } \\
\text { labour) and the State for mediation }\end{array}$ \\
\hline Rights & $\begin{array}{l}\text { Coordinates, monitors and evaluates } \\
\text { policies, promotes participation and } \\
\text { guides different publics. }\end{array}$ & $\begin{array}{l}\text { Marginalised from the political system (popular and } \\
\text { identity movements). }\end{array}$ \\
\hline Funds & $\begin{array}{l}\text { Approves plans of accounts and fund } \\
\text { management reports. } \\
\text { Judges processes and grants benefits to } \\
\text { certain organisations. }\end{array}$ & $\begin{array}{l}\text { Interests in conflict (e.g., capital and labour) and the } \\
\text { State for mediation. }\end{array}$ \\
\hline $\begin{array}{l}\text { Governmental Advisory } \\
\text { Board }\end{array}$ & $\begin{array}{l}\text { Advisory (consultative) to the Chief of } \\
\text { executive branch. } \\
\text { Space of dialogue and pressure . }\end{array}$ & $\begin{array}{l}\text { Citizens of notorious representativeness (leaders) in } \\
\text { various sectors: private companies, social movements, } \\
\text { trade unions. }\end{array}$ \\
\hline
\end{tabular}

Source: Elaborated by the authors based on Teixeira et al. (2012, pp. 58-59) and findings of this research.

Secondly, this research highlights some participation limits regarding members performance. CCSP advisers have relative discretion regarding numerous actions - proposing the agenda of meetings, presenting their points of view, criticising / praising government policies, and suggesting projects - but they have no decision-making power, which is concentrated in the executive branch.

\section{CLOSING REMARKS}

The São Paulo Municipal Advisory Board is an innovative channel of communication between civil society and the municipal public administration, and it was created by the former mayor of the city, Fernando Haddad (2013-2016). It is noteworthy to recognise its potential for the expansion of the public sphere for dialogue and participation.

Considering the innovation this municipal advisory board brought about, and the need for understanding different participatory institutions (Avritzer, 2012; Bishop \& Davis, 2002), this exploratory article aimed to answer two research questions linked to describing how CCSP works and its relation to other participatory councils in Brazil.

The study results indicate that CCSP converges partially with the deliberative democratic model and, more importantly, with CDES. Nevertheless, the interviewees and the literature reviewed also problematized the deliberative feature in these two institutions. For example, the interviewees highlight that members of this boards are called to give their opinions, but decision-making remains an exclusive prerogative of the mayor. Because of this, based on Bishop and Davis (2002), the Municipal 
Advisory Board' can be defined as an instrument of participation as consultation, which begins with an acknowledgment that governments decide.

Considering the results of this research and of other studies that analyse CDES, the need to revise the current typology of participatory institutions in Brazil has become clear. The proposed new type - Governmental Advisory Board - includes the experiences of CCSP and Federal and State CDES, representing spaces of dialogue and pressure that aggregate diverse representatives of society and government, in addition to serving as 'gauges' capable of indicating the adherence of different social segments to ideas and actions proposed by the executive branch.

It is interesting to note that the institution in this new category have other common traits: they deal with complex and multifaceted issues - social development and the immensity of topics in a city as complex as São Paulo; and they do not aim to create consensus or agreements, to define or evaluate policy or governmental action. They have 'limited diversity' and constitute spaces of debate, confrontation and governmental contact with the variety of social demands, points of view and interests. Therefore, it seems reasonable not to criticise them for democratic deficit, considering that these councils do not aim to involve their members directly in decision-making.

It is important to emphasise that one interviewee mentioned a concern about the discontinuity of CCSP and its dependency on political will, which posteriorly became a reality. In January 2017, the newly elected Mayor João Dória took office in the municipality of São Paulo and extinguisehd the Municipal Secretariat of Governmental Relations, replacing it with the Municipal Secretariat of Privatisation and Partnerships ${ }^{8}$, and interrupted the working dynamics then developed by the CCSP.

Finally, only broader studies - those extended over time and covering different governmental advisory boards - will give consistency to the conclusions drawn from this case study. In any case, such conclusions are points of reference for future studies that will strengthen knowledge on the effective functioning of other governmental advisory boards and their comparison to other types of councils.

${ }^{8}$ Official website: http://www.prefeitura.sp.gov.br/cidade/secretarias/desestatizacao/ 


\section{REFERENCES}

Avritzer, L. (2012, July). The different designs of public participation in Brazil: deliberation, power sharing and public ratification. Critical Policy Studies, 6(2), 113-127.

Bishop, P., \& Davis, G. (2002, March). Mapping public participation in policy choices. Australian Journal of Public Administration, 61(1), 14-29.

Beltrão, R. E. V., \& Nogueira, F. A. (2011). The documentary research in recent studies in public administration and social management in Brazil. In Anais do $35^{\circ}$ Encontro da ANPAD. Rio de Janeiro, RJ, Brasil.

Casula, M. (2017). Who governs in (local) governance? Theorical considerations and empirical evidence. Revista de Administração Pública, 51(6), 1121-1138.

Crantschaninov, T. I. (2018). Da expectativa à (des)mobilização: a trajetória da participação nas conferências da Defensoria Pública do Estado de São Paulo (Doctoral Dissertation). Escola de Administração de Empresas de São Paulo, Fundação Getulio Vargas, São Paulo, Brazil.

Coelho, V. S. P. (2013). What did we learn about citizen involvement in the health policy process: lessons from Brazil. Journal of Public Deliberation, 9(1), 1-17.

Coelho, V. S. P. (2014). A brief reflection on the Brazilian participatory experience. Journal of Public Deliberation, 10(1), 1-4.

Cohn, A. (2011) Participação social e conselhos de políticas públicas. Brasília, DF: IPEA, 2011. (Texts for discuss CEPAL-IPEA 29).

Cornwall, A. (2006). Introduction: New democratic spaces? The politics and dynamics of Institutionalized Participation. IDS Bulletin, 35(2): 1-10.

Cornwall, A., Coelho, V. S. P. (2006). Spaces for change? The politics of participation in new democratic arenas. In A. Cornwall, \& V. S. P. Coelho (Eds.). Spaces for Change?: The Politics of Citizen Participation in New Democratic Arenas (Claiming Citizenship). London, UK: Zed Books.

Fleury, S. (2006). O Conselho de Desenvolvimento Econômico e Social do governo Lula. In P. E. M. Martins, \& O. P. Pieranti (Eds.). Estado e Gestão
Pública: Visões do Brasil Contemporâneo (2. Ed., pp. 79-105). Rio de Janeiro, RJ: Editora FGV.

Lima, P. P. F. et al. (2014). Conselhos Nacionais: elementos constitutivos para sua institucionalização. Brasília, DF: IPEA. (Textos para discussão, n 1951).

Miles, M. B., \& Huberman, A. M. (1994). Qualitative data analysis: an expanded sourcebook (2nd ed.). Thousand Oaks, CA: Sage Publications.

Nobre, M. (2004). Participação e deliberação na Teoria Democrática: uma introdução. In V. S. P. Coelho, \& M. Nobre (Eds.), Participação e deliberação: Teoria democrática e experiências institucionais no Brasil contemporâneo (pp. 21-40). São Paulo, SP: Editora 34.

O’Donnell, G. (1976). Sobre o corporativismo e a questão do Estado. Cadernos do DCP, 3, 1-54.

Pinto, C. R. J. (2004). Espaços deliberativos e a questão da representação. Revista Brasileira de Ciências Sociais, 19, 97-16.

Santos, P. R. (2016) Inovações participativas, diálogo social e construção de consensos. Revista de Administração Pública, 50(3), 501-511.

Souto, A. L. S., \& Paz, R. D. O. (2012). Novas lentes sobre a participação: utopias, agendas e desafios. São Paulo, SP: Instituto Pólis.

Stake, R. E. (2008). Qualitative case studies. In N. K. Denzin, \& Y. S. Lincoln (Eds.), Strategies of qualitative inquiry (pp. p. 119-149). Thousand Oaks, CA: Sage Publications.

Szwako, J. (2012). Participar vale a pena, mas...: a democracia participativa brasileira vista pelas lentes da utopia. In A. L. S. Souto, \& R. D. Paz (Eds.), O. Novas lentes sobre a participação: utopias, agendas e desafios (pp. 13-44). São Paulo, SP: Instituto Pólis.

Teixeira, A. C. C., Souza, C. H. L., \& Lima, P. P. F. (2012). Arquitetura da participação no Brasil: uma leitura das representações políticas em espaços participativos nacionais. In A. L. S. Souto, \& R. D. $\mathrm{Paz}$ (Eds.), O. Novas lentes sobre a participação: utopias, agendas e desafios (pp. 49-76). São Paulo, SP: Instituto Pólis.

Vizeu, F., \& Bin, D. (2008). Democracia deliberativa: leitura crítica do caso CDES à luz da teoria do discurso. Revista de Administração Pública, 42(1), 83-108. 
Wampler, B. (2010). Transformando o Estado e a Sociedade Civil por meio da Expansão das Comunidades. In L. Avritzer (Ed.), A dinâmica da participação local no Brasil. Brasília, DF: Cortez.

Young, I. M. (2001). Comunicação e o outro: além da democracia deliberativa. In J. Souza (Ed.),
Democracia hoje: novos desafios para a teoria democrática contemporânea (pp. 365-386). Brasília, DF: Editora UNB.

Young, I. M. (2006). Representação política, identidade e minoria. Lua Nova, 67, 139-190.

\section{Fernanda Lima-Silva}

https://orcid.org/0000-0003-4838-7075

$\mathrm{PhD}$ in Public Administration and Government at Fundação Getulio Vargas School of Business Administration in São Paulo (FGV EAESP). E-mail: fernanda.silva@fgv.br

\section{Kate Abreu}

https://orcid.org/0000-0002-5229-5504

$\mathrm{PhD}$ in Public Administration and Government at Fundação Getulio Vargas School of Business Administration in São Paulo (FGV EAESP). E-mail: katedayana@gmail.com

\section{Esther M. Leblanc}

https://orcid.org/0000-0002-1885-6195

Master in Public Administration and Government at Fundação Getulio Vargas School of Business Administration in São Paulo (FGV EAESP). E-mail: estherleblanc@gmail.com 
RAP | Consultative participation in Brazil: the case of the São Paulo Municipal Advisory Board

\section{ANNEX}

\section{Interview questionnaire}

1. Could you briefly comment on your professional career and your role in the CCSP?

2. Could you comment on why and how the CCSP was created?

3. What criteria were used for the advisers selection?

4. Does the CCSP manage any funds?

5. Does the CCSP formulate policies?

6. Does the CCSP implement policies or evaluate public policies?

7. Who sets the agenda for the CCSP meetings?

8. What topics are usually covered in the agenda of the Municipal Advisory Board meetings?

9. Do people from opposition parties participate in the Municipal Advisory Board?

10. In practice, how does the Municipal Advisory Board advise the Mayor?

11. What do you see as positive in the CCSP?

12. What do you see as negative in the CCSP?

13. What were your initial expectations of the CCSP? Were your expectations met? 